\title{
Compact Solar Combisystem for an Apartment Building
}

\author{
Alona Bolonina, Institute of Energy Systems and Environment, Riga Technical University, Claudio Rochas, Institute \\ of Energy Systems and Environment, Riga Technical University, Inese Kibure, Institute of Energy Systems and \\ Environment, Riga Technical University, Marika Rosa, Institute of Energy Systems and Environment, Riga Technical \\ University, Dagnija Blumberga, Institute of Energy Systems and Environment, Riga Technical University
}

\begin{abstract}
The Riga Technical University Institute of Energy Systems and Environment, in cooperation with three Latvian companies, is implementing the project "Compact solar and pellet module" financed by the European Union. Within the framework of this project a combisystem will be installed in the Grandeg Ltd modular pellet boiler house. The solar combisystem will provide domestic hot water and space heating load for an apartment building in Sigulda. Due to the limited amount of space in the modular boiler house, optimal decisions should be made on the technical parameters of the system, including the volume of the heat storage tank and the surface area of solar collectors. Every alternative has both advantages and disadvantages. Economic factors of various alternatives are analyzed.
\end{abstract}

Keywords - combisystem, solar energy, pellet boiler, solar heating system, modular boiler house.

\section{INTRODUCTION}

One of the obstacles for using renewable energy sources (RES) are the rather high costs of RES technologies, although, it has to be mentioned, that during the last decade RES technologies have been successfully developing. Therefore an increase in the efficiency of installations, as well as a decrease of the costs due to the development of RES equipment step-by-step make it possible to lower the costs of RES technologies on a similar level to the costs of traditional energy sources. The growth of RES competitiveness and the wider use of RES technologies can decrease a country's dependence on energy import, improve the balance of external costs, promote job creation, as well as decrease environmental impact [1].

Many RES technologies, such as solar collectors and heat pumps, are not widely used in Latvia due to their costs and no possibility to generate $100 \%$ of the heating demand. This is the main reason why there is a need to develop heating combisystems, which mostly use two sources of energy. The main principles of combisystems are:

- $\quad$ Production of energy from available sources;

- Storage of heat;

- Rational consumption of stored energy in the heating and domestic hot water system [2].

Various types of combisystems have already entered the European market. In the Baltic market different types of systems, combining traditional heating systems together with alternative energy sources (geothermal, solar energy), are also being offered to consumers.

The use of solar energy in Latvia has certain limitations. The distribution of solar radiation on the horizontal surface and the amount of heat which can be produced during different seasons is very variable:

- May-September - $700-740 \mathrm{kWh} / \mathrm{m}^{2}$ of solar collector;

- $\quad$ October - April - $200-240 \mathrm{kWh} / \mathrm{m}^{2}$;

- November - February - $40-50 \mathrm{kWh} / \mathrm{m}^{2}$ [3].

Solar energy cannot provide the necessary amount of heat during all seasons. In the period from May until September, the system provides $60-70 \%$ of the heat necessary for domestic hot water. During the autumn and spring months, the heating system demand can be provided by $60-70 \%$. During the winter months $30 \%$ of domestic hot water can be heated using solar energy. Thus it is necessary to install additional heating sources, which can cover the heating needs completely. Automatic control of such a system is very important to provide continuous heat supply corresponding to the heat demand.

Solar combisystems generally consist of different subsystems and elements, and as a result are typically complex systems. These interactions affect the overall performance of the solar part of the system. The general complexity of solar combisystems has led to the development of a large number of widely differing system designs and different concepts [4].

One of the types of combisystems which uses two renewable energy sources and is able to provide the entire amount of heat necessary during all the seasons and can be controlled automatically, is a combisystem of solar collectors and pellet boiler [1].

\section{COMBISYSTEM FOR AN APARTMENT BUILDING IN SIGULDA}

Since August 2009, the Riga Technical University Institute of Energy Systems and Environment, in cooperation with three Latvian companies Grandeg Ltd, VIA - S Ltd and Taupi Ltd, has been implementing the project "Compact solar and pellet module" financed by the European Union financial instrument [2].

Within the framework of the project, a combisystem of solar collectors and a pellet boiler will be developed. The system will supply heat for an apartment building in 
Sigulda, K.Barona Street 12, which complies with the main characteristics required. The building was built according to the 103rd series standard project with 4 stories and 3 staircases. The external walls of the building are made of clay bricks and concrete panels. The building has plane roof and an attic. The heating unit and boiler room are placed in the basement. The building includes 30 apartments with a total heating area of $1746 \mathrm{~m}^{2}$ [5].

The reconstruction of the heating unit and boiler room was conducted and two natural gas boilers with high efficiency were installed. The renovation of balconies and doors is being completed. The windows (depending on their condition) were replaced with new windows or renovated. The roof condition is technically acceptable, no rainfall water drain or damages are observed. Due to the current condition of the building energy demand per $1 \mathrm{~m}^{2}$ is rather high. The energy efficiency of the building will be increased by insulating the external walls. According to the current heat demand of the building, the annual heat

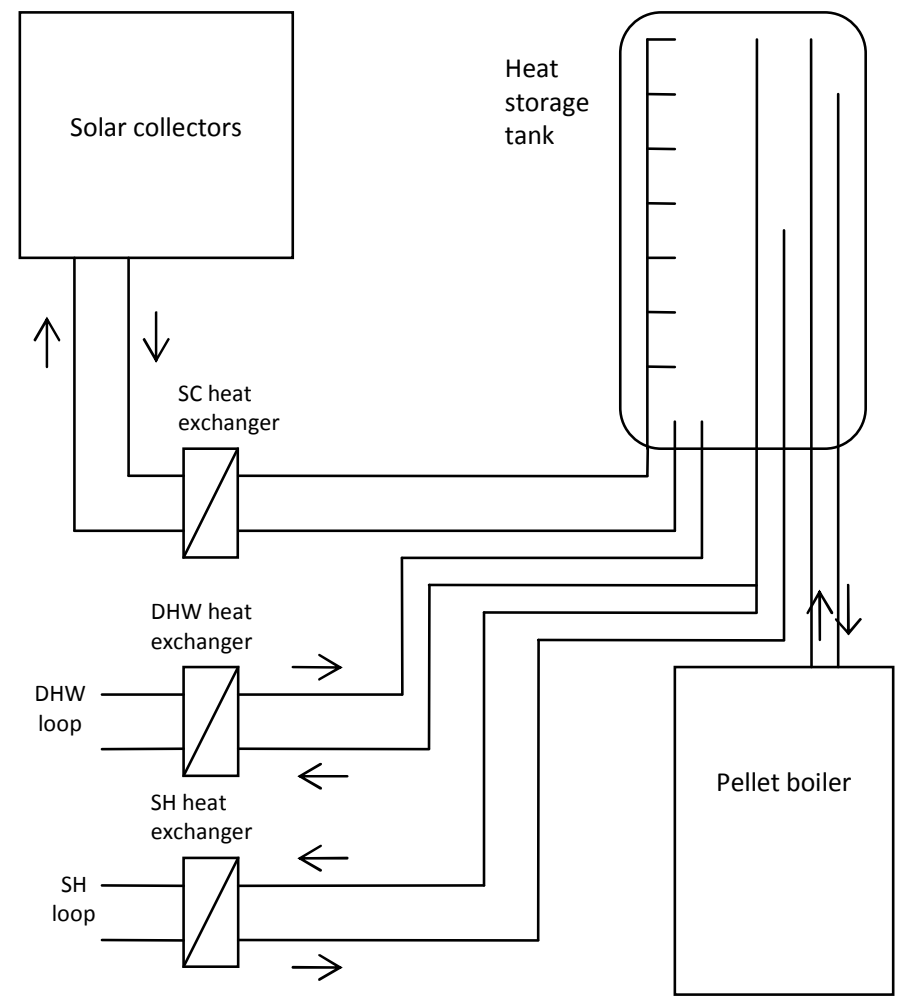

Fig. 1. Principial scheme of the solar combisystem.

The solar collectors will be placed on the roof of the building. The boiler house will be connected to the heating, cold and hot water, and electrical systems of the building. The pellet boiler will operate as the main heating source for space heating and domestic hot water demand. When solar radiation level is high, the solar collectors will operate to supply heat which initially will be stored in a heat storage tank and consumed when necessary.

Originally, the Grandeg Ltd modular boiler house equipment is placed as follows: pellet boiler in one part of the boiler house, pellet tank and pneumatic pellet feeding system in the other part of boiler house. The aim of the consumption for space heating and domestic hot water is about $260 \mathrm{MWh}$. Taking into account the range of outdoor temperature throughout the year, the necessary pellet boiler load is $100 \mathrm{~kW}$ [2].

\section{COMBISYSTEM DESCRIPTION}

One of the cooperation partners in this project is the company Grandeg Ltd which has recently begun production and distribution of modular type boiler houses. This type of boiler house will be used to develop the combisystem. The combisystem will include:

- $\quad$ Pellet boiler GD-TURBO-100;

- Pellet storage tank;

- Vacuum tube solar collector;

- Heat storage tank with a stratification device;

- Automatic control system.

The principial scheme of solar combisystem is shown in Fig. 1. project is to develop a solar combisystem on the basis of the mentioned model of the modular pellet boiler house. In this system solar collectors will be connected to the pellet boiler and an additional area will be needed for the heat storage tank. The size of the modular boiler house is $6 \times 2.9 \mathrm{~m} \mathrm{[2]}$. Originally, it includes two sections: pellet boiler section and pellet storage section.

Taking into account the limited area of the boiler house, a decision should be made on the following parameters:

- The volume of the heat storage tank, $\mathrm{m}^{3}$;

- The number and the total volume of the pellet storage tanks. 
Each of the possible alternatives is technically feasible and has both advantages and disadvantages, which impact the economic effectiveness of the system. The summary of main advantages and disadvantages of various equipment combinations is given in Table I.
Five possible alternatives for the placement of the equipment in the boiler house are analyzed.

The alternatives are shown in Table 2.

Fig. 2. describes the possible placement of the system equipment for the alternatives 2 and 4.

TABLE I

ADVANTAGES AND DISADVANTAGES OF ALTERNATIVE EQUIPMENT COMBINATIONS

\begin{tabular}{|c|c|c|}
\hline Alternatives & + & - \\
\hline $\begin{array}{l}\text { Small number of pellet tanks and larger } \\
\text { volume of storage tank }\end{array}$ & $\begin{array}{l}\text { - } \\
\text { - } \\
\text { - } \\
\text { Lossibility to store larger amount of heat } \\
\text { fraction }\end{array}$ & $\begin{array}{l}\text { - Pellets to be bought in small amounts } \\
\text { therefore at a higher price } \\
\text { - } \\
\text { - } \\
\text { Hdditional costs for transporting pellets } \\
\text { collectors }\end{array}$ \\
\hline $\begin{array}{l}\text { Greater number of pellet tanks and lower } \\
\text { volume of heat storage tank }\end{array}$ & $\begin{array}{l}\text { - } \\
\text { - } \\
\text { - } \\
\text { Lower pellet transporting costs } \\
\text { collectors of pellets }\end{array}$ & 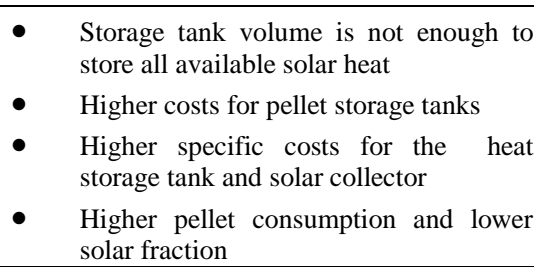 \\
\hline
\end{tabular}

TABLE II

THE ANALYZED ALTERNATIVE EQUIPMENT COMBINATIONS

\begin{tabular}{|l|l|l|l|l|l|}
\hline & $\mathbf{1}$ & $\mathbf{2}$ & $\mathbf{3}$ & $\mathbf{4}$ \\
\hline Heat storage tank & - & $2.35 \mathrm{~m}^{3}(1 \mathrm{tank})$ & $4.7 \mathrm{~m}^{3}(2 \operatorname{tanks})$ & $7.05 \mathrm{~m}^{3}\left(2 \operatorname{tanks}^{2}\right.$ & $11 \mathrm{~m}^{3}\left(1 \operatorname{tank}^{2}\right.$ \\
\hline Pellet storage tank & $11 \mathrm{t}(4 \mathrm{tanks})$ & $8.25 \mathrm{t}(3 \operatorname{tanks})$ & $5.5 \mathrm{t}(2 \operatorname{tanks})$ & $2.75(1 \mathrm{tank})$ \\
\hline
\end{tabular}

*in this alternative pellets are purchased and stored without storage tank in $16 \mathrm{~kg}$ packages

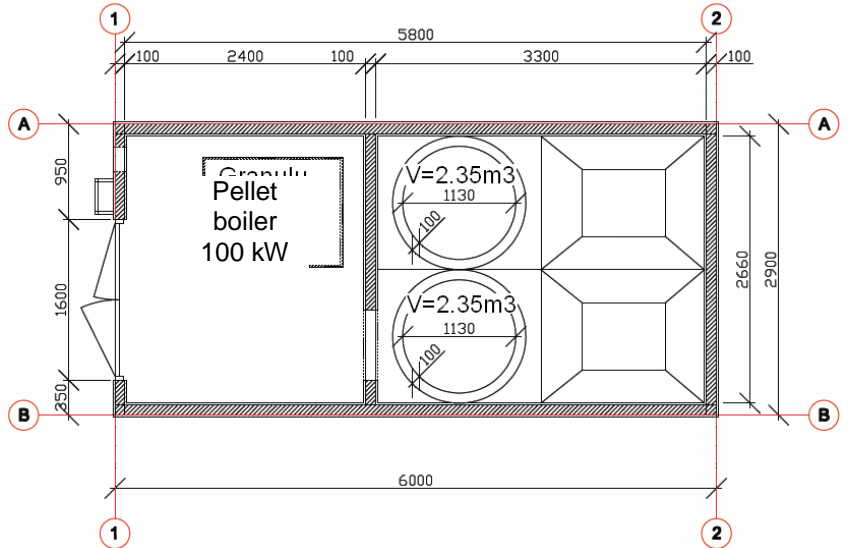

Fig. 2. The possible placement of the equipment in the modular boiler house [2].

\section{ANALYSIS}

The sizing of a solar space heating system for a building is a complex problem involving a number of interrelated factors and parameters which include, among others, the building thermal characteristics, the collector size and slope, the storage tank size, the heat exchanger size, the solar radiation, and a good number of economic parameters [6].

The effectiveness of the solar combisystem is based on the possibility to achieve a high solar fraction and minimize the consumption of pellets. The solar fraction is influenced both by the surface area of the solar collector and by the volume of

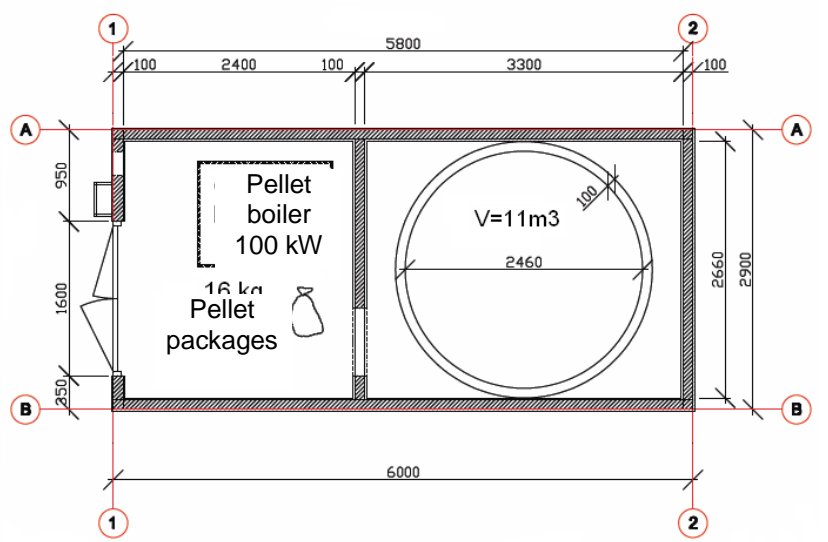

the heat storage tank. The economic factor is also important the higher the costs of the produced energy of the system will be, the less competitive such a system will be. To find an optimal combination of different parameters, the analysis of the alternatives is necessary.

The thermal characteristics of the system for each alternative are defined using TRNSYS simulation model, which is based on the model of solar combisystem described in the scientific article [7]. The model includes solar collector, collector loop, heat storage, auxiliary boiler, building load, domestic hot water profile, pumps, valves and control systems [8]. 
The main parameters used to characterize the annual energy balance of the system are:

- amount of heat produced by the solar collectors, $\mathrm{MWh} /$ year;

- $\quad$ amount of heat produced by the pellet boiler, MWh/year;

- domestic hot water demand, MWh/year;

- $\quad$ space heating demand, MWh/year;

- heat losses, MWh/year [2].

The mentioned parameters characterize the annual situation taking into account seasonal changes in the operation of the system.

One of the important parameters of a solar combisystem is the surface area of solar collectors. The results of investigations and practical experience show that the range of optimal volume of the heat storage tanks for solar collectors is 50-75 1 per $1 \mathrm{~m}^{2}$ of solar collector [9]. Based on the average optimal volume of the heat storage tank $\left(601 / \mathrm{m}^{2}\right)$, the optimal surface area of solar collectors was assumed as follows:

- $\quad 2.35 \mathrm{~m}^{3}$ storage tank $-40 \mathrm{~m}^{2}$ solar collector;

- $\quad 4.7 \mathrm{~m}^{3}$ storage tank $-80 \mathrm{~m}^{2}$ solar collector;

- $7.05 \mathrm{~m}^{3}$ storage tank - $120 \mathrm{~m}^{2}$ solar collector;

- $11 \mathrm{~m}^{3}$ storage tank $-180 \mathrm{~m}^{2}$ solar collector.

The $1^{\text {st }}$ alternative (Table II) means that the system consists of the pellet boiler only.

The analysis of optimal combisystem taking into account mentioned limitations is based on economic parameters - the necessary investments and operational costs, which form the total specific costs of the system (Ls/MWh). The parameters which are constant for all the alternatives (such as equipment maintenance and the costs of the pellet boiler) are not included.

The following costs are taken into account for each alternative combination:

- the price of a vacuum tube solar collector;

- installation costs for the solar collector;

- pellet price;

- the costs of the pellet tank;

- the costs of the pellet storage tank (including specific constructions);

- the costs of the heat storage tank;

- transportation costs for one load (the number of loads depends on the maximum amount of pellets to be stored in the boiler house).

An assumption is made that the time of system operation is 20 years.

\section{RESULTS}

Using solar radiation data, the amount of heat, which can be produced in each alternative of solar combisysem, was defined. The advantages of a larger solar collector surface area in combination with larger volume of heat storage tank are noticeable. However the analysis of the project implementation costs shows different results. Fig. 3 indicates the ratio of combisystem initial investment costs and the total amount of the heat produced and its dependence on the volume of the heat storage tank. The alternative with the 11 $\mathrm{m}^{3}$ storage tank has the highest investment costs. The lowest investment costs can be achieved by excluding installation of solar collectors and heat storage tank.

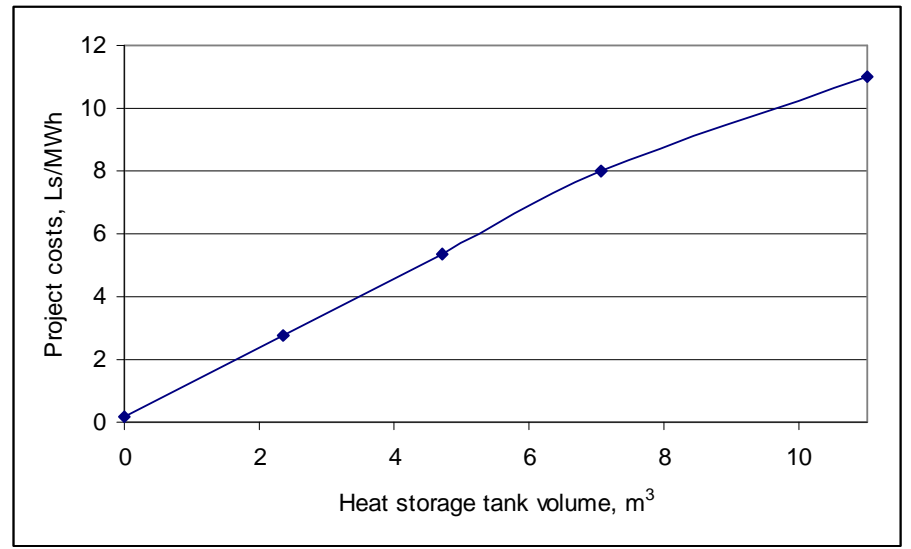

Fig. 3. Project implementation specific costs.

Fig. 4 shows the costs of the energy produced by the combisystem taking into account only operational costs. The combination of $180 \mathrm{~m}^{2}$ and $11 \mathrm{~m}^{3}$ still shows the highest costs. Comparing with combinations of solar collectors with 2.35 and $4.75 \mathrm{~m}^{3}$ heat storage tanks, the alternative without solar collectors and heat storage tanks (Fig.5 - the value of the heat storage tank is 0 ) has significantly higher operational costs due to the higher pellet consumption.

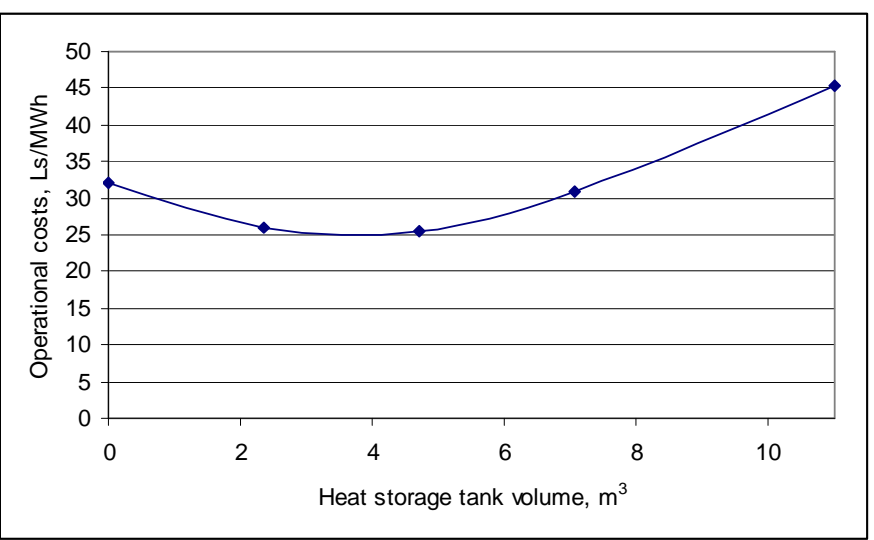

Fig. 4. Specific operational costs.

Due to the high project implementation and operational costs, the alternative with the $11 \mathrm{~m}^{3}$ heat storage tank has the highest energy costs as is shown in Fig. 5. A considerable part of the costs is formed by pellet transporting costs, which are significant if pellet storage tanks are not used.

Smaller area solar collectors in combination with smaller volume storage tank have the lowest energy costs due to lower project implementation costs and the possibility to minimize operational costs by storing large amounts of pellets.

Despite the lowest pellet consumption and the highest solar fraction to be achieved, the $5^{\text {th }}$ alternative is not economically reasonable. 


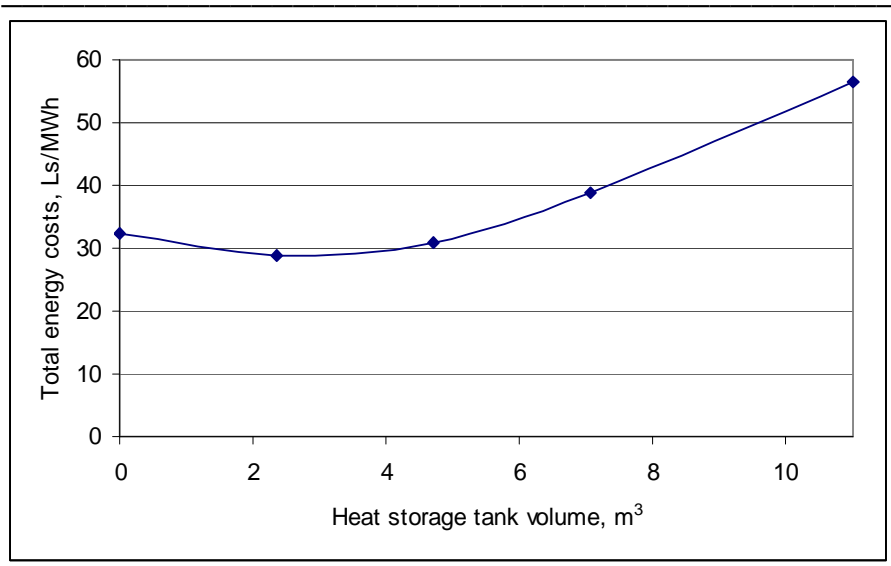

Fig. 5. Energy costs based on combisystem operational costs.

\section{CONCLUSIONS}

Within the framework of the combisystem project, an investigation of the optimal economic parameters was made for a multi-storey building in Sigulda. To integrate the solar combisystem into the existing commercially-available system, the modular type boiler house can be used. Therefore, the available area was limited by the standard size of the boiler house.

The results of the analysis indicate that despite the fact that solar collectors with a larger area in combination with a larger volume heat storage tank can achieve high solar fraction and save resources by decreasing pellet consumption, both operational and investment costs of these systems are significantly high. The results also show that the pellet storage tank in the modular boiler house is an important factor to achieve lower operational costs and indirectly decrease environmental impact due to rational transporting of the pellets.

The compact solar combisystem with optimal parameters and equipment can achieve good economic value and become advantageous for consumers comparing with the system without solar collectors and heat storage tank.

The decision on the technological characteristics of the solar combisystem should be based on existing economic, environmental and other possible limitations. To develop the system with optimal solar fraction, fuel consumption and the energy costs, the solar combisystem with $40 \mathrm{~m}^{2}$ solar collector, $2.3 \mathrm{~m}^{3}$ heat storage tank and 2 pellet storage tanks (for $5.5 \mathrm{t}$ of pellets) should be chosen for the apartment building in Sigulda.

\section{REFERENCES}

1. Kanceviča L., Ziemelis I. Saules starojums - ekoloǵiski tīrs enerğijas avots: Starptautiskās zinātniskās konferences materiāli, 2006.g. 11.-12. maijs, Rīga, Latvija.

2. Kibure I. Daudzdz̄ivokḷu ēkas siltumapgādes kombisistēma. Mağistra darbs. Rīgas Tehniskā universitāte, Rīga, Latvija, 2010. - 89 p.

3. Kanceviča L. Pētījums par ūdens sildīšanu ar saules radiāciju: Starptautiskās zinātniskās konferences materiāli, 2007.g. 10-11. maijs, Rīga, Latvija

4. Weiss W. Solar heating system for houses. A design handbook for solar combisystems. - London: James\&James, 2003. - 313 p.

5. Greķis A. Ėkas energoaudita atskaite. - Rīga: SIA Horus Laboratory, 2008. -35 p.

6. Michaelides I. M., Wilson D. R. Optimization of design criteria for solar space heating systems through modeling and simulation. Renewable Energy, Vol. 9, Issues 1-4, 1996. - 5 p.

7. Jaunzems D., Rochas C. Development of solar combisystem control algorithm and simulation model: Scientific Proceedings of Riga Technical University scientific conference, Riga, Latvia, October 2006. -11 p.

8. Rochas C. Experimental analysis of solar combisystems. Optimization. PhD Thesis. Riga Technical University, Riga, Latvia, 2008. - 123 p.

9. Schnauss M., Remmers K., Peuser F.A. Solar thermal systems. Berlin: Solarpraxis AG, 2002. - 364 p.

Alona Bolonina, M.sc., PhD student

Address: Institute of Energy Systems and Environment, Riga Technical University

Address: Kronvalda blvd. 1, Riga, LV 1010, Latvia

Phone: +37126465373

e-mail: alona.bolonina@rtu.lv

Claudio Rochas, Dr.sc.ing.

Institute of Environment and Energy Systems, Riga Technical University

Address: Kronvalda blvd. 1, Riga, LV 1010, Latvia

Phone: 37167089923,37167089908 ,

Fax: 37167089908

e-mail: claudio.rochas@rtu.lv

Inese Kibure, M.sc.

Institute of Energy Systems and Environment, Riga Technical University

Kronvalda boulv.1, LV-1010, Riga, Latvia

Phone: +37126465373

e-mail: inese.kibure@rtu.lv

Marika Rosa, Dr.sc.ing., Assistant Profesor

Institute of Environment and Energy Systems, Faculty of Energy and

Electrical Engineering, Riga Technical University

Address: Kronvalda blvd. 1, Riga, LV 1010, Latvia

Phone: 371 67089923, 37167089908 ,

Fax: 37167089908

e-mail: marika.rosa@rtu.lv

Dagnija Blumberga, Dr.habil.sc.ing., professor

Institute of Environment and Energy Systems, Faculty of Energy and

Electrical Engineering, Riga Technical University

Address: Kronvalda blvd. 1, Riga, LV 1010, Latvia

Phone: 371 67089923, 37167089908 ,

Fax: 37167089908

e-mail: dagnija.blumberga@rtu.lv

Aḷona Boloṇina, Claudio Rochas, Inese Kibure, Marika Rošā, Dagnija Blumberga. Kompakta saules kombisistēma daudzdz̄ivokḷu ēkai

Rīgas Tehniskās universitātes Vides aizsardzības un siltuma sistēmu institūts sadarbībā ar trīs Latvijas uzņēmumiem realizē projektu „Kompaktais saules un granulu modulis". Projektu finansē Eiropas Savienība. Projekta ietvaros SIA Grandeg moduḷa katlu mājā tiks uzstādīta saules kombisistēma. Saules kombisistēma nodrošinās karstā ūdens piegādi un apkures vajadzības daudzdzīvokḷu ēkai Siguldā (Latvija). Katlu mājas ierobežoto izmēru dēḷ nepieciešams pieņemt optimālu lēmumu par sistēmas tehniskajiem parametriem, ieskaitot siltuma akumulācijas tvertnes tilpumu un saules kolektoru laukumu.

Lai raksturotu ēku un noteiktu tās siltumenerǵijas patērinu, tika izmantoti energoaudita dati. TRNSYS modelis ir izmantots, lai aprēkinātu apkures sistēmas siltuma bilanci, n̦emot vērā sezonālo saules radiāciju, nepieciešamo siltumslodzi, papildus siltuma avota darbību un siltuma zudumus sistēmā (ietverot siltuma akumulācijas tvertni).

Lai noteiktu dažādu parametru optimālo kombināciju, ir veikta dažādu kombisistēmas sastāvdalu kombināciju izmaksu analīze.

Analīzes rezultātā atrasta no izmaksu viedokḷa optimāla saules kolektora laukuma un siltuma akumulācijas un granulu uzglabāšanas tvertṇu kombinācija. 
Алена Болонина, Клаудио Роша, Инесе Кибуре, Марика Роша, Дагния Блумберга. Компактная солнечная комбисистема для многоквартирного здания

Институт охраны окружающей среды и тепловых систем Рижского технического университета совместно с тремя Латвийскими компаниями реализует проект «Компактный солнечный и гранульный модуль». Проект финансирует Европейский союз. В рамках проекта в модульной котельной ООО «Grandeg» будет установлена солнечная комбисистема. Система обеспечит расход тепла на горячую воду и отопление для многоквартирного дома в Сигулде (Латвия). Из-за ограниченных размеров котельной, необходимо принять оптимальные решения о технических параметрах системы, включая объем бака-аккумулятора тепла и площадь солнечных коллекторов.

Чтобы охарактеризовать здание и планируемый расход тепла, использованы данные энергоаудита. Для расчета теплового баланса системы, с учетом сезонного солнечного излучения, тепловой нагрузки, работы дополнительного источника тепла и потери тепла в системе (с учетом бакааккумулятора), использована модель системы в программе TRNSYS.

Для того, чтобы определить оптимальную комбинацию параметров, был проведен анализ стоимости различных вариантов составляющих системы.

В результате анализа определена оптимальная комбинация площади солнечного коллектора, объема бака-акумулятора тепла и бака для хранения гранул. 